\title{
RUMUSAN STRATEGI BISNIS SUB TERMINAL AGRIBISNIS CIGOMBONG KECAMATAN PACET KABUPATEN CIANJUR
}

\author{
Oleh : \\ Ismi Ajeng*) \\ Rani Diana**)
}

\begin{abstract}
Abstrak
STA Cigombong sebagai sarana pemasaran produk pertanian yang dapat membantu petani dalam memasarkan hasil pertaniannya. Untuk itu STA perlu merumuskan strategi yang tepat agar bisa terus maju dan berkembang di dalam bisnis pertanian. Tujuan dari penelitian ini adalah untuk mengetahui faktor internal dan faktor eksternal yang menjadi kekuatan, kelemahan, peluang dan ancaman bagi STA Cigombong dan untuk merumuskan strategi STA Cigombong. Penelitian ini menggunakan analisis deskriptif kualitatif dan kuantitatif. Alat bantu analisis yang digunakan untuk merumuskan strategi yaitu matriks IFE, EFE, IE, SWOT, dan QSPM. Dari matriks IFE diperoleh total bobot skor rata-rata sebesar 3,03 yang berarti STA memiliki internal kuat dan matriks EFE diperoleh total bobot skor rata-rata sebesar 2,83 yang berarti STA memiliki eksternal sedang sehingga diperoleh posisi STA Cigombong berada pada kuadran IV yang berarti tumbuh dan kembangkan. Dari analisis SWOT menghasilkan sebelas strategi. Adapun hasil dari QSPM prioritas strategi yang memiliki skor lebih tinggi dan menjadi prioritas utama dari alternatif strategi lainnya yaitu meningkatkan kualitas dan mengoptimalkan peran STA.
\end{abstract}

Kata kunci: Faktor internal, Faktor eksternal, Strategi bisnis.

\begin{abstract}
STA Cigombong as a means of marketing agricultural product that can assist farmers in marketing their agricultural products. For this reason, STA needs to formulate the right strategy so that it can continue to advance and develop in the agricultural business. The purpose of this study is to determine the internal and external factors which are the strengths, weaknesses, opportunities and threats of STA Cigombong and to formulate a strategy for STA Cigombong. This research uses qualitative and quantitative descriptive analysis. The analysis tools used to formulate strategies are the IFE, EFE, IE, SWOT, and QSPM matrices. From the IFE matrix obtained an average total weight score of 3.03 which means that STA has a strong internal and the EFE matrix obtained an average weight score of 2.83 which means that STA has a moderate external so that the position of STA Cigombong is in quadrant $I V$ which means to grow and develop. From the SWOT analysis, eleven strategies were generated. The results of the QSPM priority strategy have a bigber score and become the top priority of other alternative strategies, namely improving quality and optimizing the role of STA.
\end{abstract}

Keywords: Internal factors, External factors, Business strategy.

*) Dosen Fakultas Sains Terapan UNSUR.

**) Alumni Fakultas Sains Terapan UNSUR.

$\begin{array}{lccr}\text { RUMUSAN } & \text { STRATEGI } & \text { BISNIS } & \text { SUB } \\ \text { TERMINAL } & \text { AGRIBISNIS } & \text { CIGOMBONG } \\ \text { KECAMATAN } & \text { PACET } & \text { KABUPATEN } \\ \text { CIANJUR } & & \end{array}$




\section{PENDAHULUAN}

Sektor pertanian merupakan salah satu sektor yang mempunyai peranan penting dalam perekonomian Indonesia. Hal tersebut dikarenakan sektor pertanian merupakan sumber pendapatan bagi sebagian penduduk Indonesia. Menurut Badan Pusat Statistik (2018), sebanyak $88,27 \%$ penduduk Indonesia bekerja di sektor pertanian.

Sektor pertanian terdiri dari beberapa subsektor, di antaranya subsektor hortikultura, tanaman pangan, perkebunan, perikanan, kehutanan, dan juga peternakan. Dilihat dari aspek ekonominya, sub sektor hortikultura sampai tahun 2018 tetap menjadi kontributor penting dalam pembangunan ekonomi nasional. Salah satu daerah penghasil komoditas hortikultura adalah provinsi Jawa Barat. Menurut Badan Pusat Statistik (2017) Jawa Barat merupakan salah satu daerah penghasil sayuran dan buah-buahan. Cianjur adalah suatu kabupaten yang ada di Jawa Barat yang memiliki potensi di sektor pertanian seperti tanaman pangan dan hortikultura. Menurut Badan Pusat Statistik (2017), pada tahun 2015 penduduk kabupaten Cianjur yang bekerja di sektor pertanian, kehutanan, perburuan, dan perikanan yaitu sekitar 35,97\%.

Kecamatan Pacet merupakan salah satu kecamatan yang berada di wilayah Kabupaten Cianjur yang didominasi oleh tanaman sayuran dan tanaman hias (Pemerintah Provinsi Jawa Barat, 2017). Oleh karena itu kecamatan Pacet dapat dikatakan sebagai daerah yang mempunyai potensi sebagai penghasil produk pertanian terutama komoditas hortikultura. Selama ini pemasaran produk pertanian masih menjadi suatu kendala bagi sebagian petani. Dengan hasil produk yang dimiliki terkadang petani kesulitan dalam memasarkan hasil pertaniannya dan terkadang pendapatan yang diperoleh pun relatif kecil. Untuk itu salah satu upaya yang dapat dilakukan untuk membantu petani meningkatkan nilai tambah petani juga meningkatakan efisiensi pemasaran dengan mengembangkan infrastruktur pemasaran seperti Sub Terminal Agribisnis (STA).

Di Kecamatan Pacet terdapat Sub Terminal Agribisnis (STA) yang biasa dikenal dengan STA Cigombong. STA Cigombong ini sebagai sarana pemasaran produk pertanian yang dapat membantu para petani dalam memasarkan hasil pertaniannya, membantu petani untuk meningkatkan nilai tambah, dan juga membantu dalam meningkatkan pengetahuan petani. Untuk itu, keberadaan STA ini sangat penting.

Dalam suatu kegiatan pemasaran di dunia bisnis, tidak terlepas dari adanya persaingan. Para pelaku bisnis pasti memiliki strateginya masing-masing untuk dapat menghadapi persaingan. Melihat persaingan yang semakin lama semakin ketat, maka para pelaku bisnis akan dituntut untuk selalu melakukan inovasi dalam strategi bersaing (Prawitasari, 2010). Hal tersebut dapat dilakukan agar para pelaku bisnis dapat menghadapi dan memenangkan persaingan di dunia industri.

Untuk dapat memenangkan persaingan, para pelaku bisnis harus mampu menyusun rencana strategis bisnis yang tepat. Salah satu alat analisis yang dapat digunakan dalam perencanaan strategis tersebut yaitu dengan menggunakan Analisis SWOT.

Dengan analisis SWOT maka keunggulan yang dimiliki STA Cigombong dapat dijadikan sebagai kekuatan untuk ditingkatkan dengan memanfaatkan peluang sebaik-baiknya untuk meminimalisir kelemahan dan ancaman yang ada seperti banyaknya lahan yang dialihfungsikan dan banyaknya pesaing yang mudah masuk ke dalam bidang yang sama menjadi sesuatu yang dapat mengancam bagi STA. Untuk itu diperlukan penelitian untuk mengetahui perumusan strategi yang tepat bagi STA agar bisa terus maju dan berkembang di dalam bisnis pertanian.

Tujuan dari penelitian ini adalah sebagai berikut:

$\begin{array}{lccr}\text { RUMUSAN } & \text { STRATEGI } & \text { BISNIS } & \text { SUB } \\ \text { TERMINAL } & \text { AGRIBISNIS } & \text { CIGOMBONG } \\ \text { KECAMATAN } & \text { PACET } & \text { KABUPATEN } \\ \text { CIANJUR } & & \end{array}$


1. Untuk mengetahui faktor internal dan faktor eksternal STA Cigombong.

2. Untuk merumuskan strategi bisnis STA Cigombong.

\section{METODE PENELITIAN}

\section{Tempat dan Waktu}

Penelitian dilaksanakan di UPTD

Sub Terminal Agribisnis (STA) dan Agropolitan yang beralamat di Jl. Raya Cigombong Ciherang no. 71 Kecamatan Pacet, Kabupaten Cianjur, Provinsi Jawa Barat. Alasan peeliti mengambil lokasi penelitian tersebut adalah karena STA Cigombong ini telah berdiri cukup lama dan merupakan salah satu sarana pemasaran yang didirikan oleh pemerintah untuk membantu petani dalam memasarkan hasil pertaniannya khususnya komoditas hortikultura. Penelitian ini dilaksanakan sejak bulan Februari sampai bulan Agustus 2020.

\section{Jenis Penelitian}

Dalam penelitian ini jenis dan sumber data yang digunakan adalah data primer dan data sekunder. Data primer merupakan data yang didapat dari sumber pertama dari individu atau perseorangan. Dalam penelitian ini data primer diperoleh dari hasil observasi lapangan, kuesioner yang telah disiapkan sebelumnya, dan wawancara dengan kepala STA Cigombong.

Sedangkan data sekunder, yaitu data yang diperoleh dari instansi seperti pemerintah atau lembaga terkait dengan berbagai literatur yang dapat menunjang penelitian. Data sekunder yang diperoleh diantaranya dari BPS Jawa Barat dan Badan Agribisnis Departemen Pertanian.

\section{Teknik Pengumpulan Data}

Menurut Arikunto (2010) teknik pengumpulan data adalah cara-cara yang dapat digunakan oleh peneliti untuk mengumpulkan data. Dalam penelitian ini, teknik pengumpulan data yang digunakan adalah sebagai berikut:

\section{Observasi}

Observasi yaitu melakukan pengamatan secara langsung ke objek penelitian untuk melihat dari dekat kegiatan yang dilakukan (Riduwan, 2010). Observasi dalam penelitian ini dilakukan dengan mengamati langsung kondisi di lapangan yaitu di STA Cigombong, melihat berbagai kegiatan yang dilakukan di STA Cigombong untuk melengkapi penulisan.

\section{Wawancara}

Menurut Arikunto (2010) wawancara adalah sebuah dialog yang dilakukan oleh pewawancara (interviewer) untuk memperoleh informasi dari terwawancara (interviewee). Dalam penelitian ini wawancara dilakukan kepada responden dengan menanyakan beberapa hal yang berkaitan dengan tujuan yang ingin dicapai dengan mengidentifikasi kekuatan, kelemahan, peluang, dan ancaman untuk dirumuskan dalam strategi bisnis.

\section{Kuesioner}

Menurut Sugiyono (2015) kuesioner adalah teknik pegumpulan data yang dilakukan dengan cara memberi seperangkat pertanyaan atau pernyataan tertulis kepada responden untuk dijawab. Dalam penelitian ini kuesioner dilakukan dengan memberi beberapa pernyataan yang berkaitan dengan faktor internal dan eksternal di STA Cigombong kepada responden.

\section{Studi Pustaka}

Menurut Sugiyono (2014) studi kepustakaan yaitu dengan menelaah bukubuku, literatur, catatan-catatan, dan laporan-laporan yang ada hubungannya dengan masalah yang dipecahkan yang berkaitan dengan penelitian.

\section{Variabel Penelitian}

Menurut Sugiyono (2015) variabel penelitian merupakan suatu atribut atau sifat ataupun nilaidari orang, objek, atau kegiatan yang mempunyai variasi tertentu yang ditetapkan oleh peneliti untuk dipelajari dan kemudian ditarik kesimpulan. Adapun variabel yang digunakan dalam penelitian.

$\begin{array}{lccr}\text { RUMUSAN } & \text { STRATEGI } & \text { BISNIS } & \text { SUB } \\ \text { TERMINAL } & \text { AGRIBISNIS } & \text { CIGOMBONG } \\ \text { KECAMATAN } & \text { PACET } & \text { KABUPATEN } \\ \text { CIANJUR } & & \end{array}$


Tabel 1. Operasional Variabel.

\begin{tabular}{|c|c|c|c|c|}
\hline Variabel & Konsep Variabel & Indikator & $\begin{array}{c}\text { Sumber } \\
\text { Data }\end{array}$ & Skala \\
\hline $\begin{array}{l}\text { Faktor } \\
\text { Internal }\end{array}$ & $\begin{array}{l}\text { lingkungan internal merupakan } \\
\text { kondisi yang ada di dalam suatu } \\
\text { perusahaan dengan memantau } \\
\text { pelaku-pelaku dalam lingkungan } \\
\text { internal yang dapat } \\
\text { mempengaruhi } \\
\text { perusahaan agar dapat mencapai } \\
\text { tujuan perusahaan. Analisis } \\
\text { internal diperlukan untuk } \\
\text { mengetahui faktor internal yang } \\
\text { terdiri dari kekuatan dan } \\
\text { kelemahan yang dimiliki } \\
\text { perusahaan (David, 2011). }\end{array}$ & $\begin{array}{l}\text { 1. Kekuatan } \\
\text { - Komunikasi yang } \\
\text { terjalin } \\
\text { - Koperasi } \\
\text { - Lokasi } \\
\text { - Kualitas produk } \\
\text { - Ketersediaan produk } \\
\text { - Pemasaran } \\
\text { 2. Kelemahan } \\
\text { - Struktur Organisasi } \\
\text { - Peran koperasi STA } \\
\text { - Rantai pemasaran }\end{array}$ & Primer & Interval \\
\hline $\begin{array}{l}\text { Faktor } \\
\text { Eksternal }\end{array}$ & $\begin{array}{l}\text { lingkungan eksternal } \\
\text { mengungkapkan peluang dan } \\
\text { ancaman utama yang dihadapi } \\
\text { suatu perusahaan sehingga } \\
\text { manajer dapat memformulasikan } \\
\text { strategi untuk mengambil } \\
\text { keuntungan dari peluang dan } \\
\text { mengindari atau mengurangi } \\
\text { dampak dari ancaman. Analisis } \\
\text { eksternal diperlukan untuk } \\
\text { mengetahui faktor eksternal yang } \\
\text { terdiri dari peluang dan ancaman } \\
\text { yang dimiliki perusahaan (David, } \\
\text { 2011) }\end{array}$ & $\begin{array}{l}\text { 1. Peluang } \\
\text { - Dukungan pemerintah } \\
\text { - Perubahan gaya hidup } \\
\text { sehat } \\
\text { - Permintaan konsumen } \\
\text { - Perluasan pasar } \\
\text { - Berkembangnya } \\
\text { teknologi } \\
\text { 2. Ancaman } \\
\text { - Alih fungsi lahan } \\
\text { - Hambatan masuk bagi } \\
\text { pesaing baru }\end{array}$ & Primer & Interval \\
\hline
\end{tabular}

\section{Populasi}

Menurut Sugiyono (2015) populasi adalah wilayah generalisasi yang terdiri dari suatu objek atau subjek yang mempunyai kualitas serta karakteristik tertentu yang telah ditetapkan oleh peneliti yang hendak dipelajari dan ditarik kesimpulan. Adapun populasi dalam penelitian ini adalah pengelola STA dan pelaku usaha yang ada di STA Cigombong yang berjumlah 9 orang yang terdiri dari 2 pengelola dan 7 pelaku usaha. Karena populasi merupakan orang-orang internal yang berpengaruh dan mengetahui serta memahami kondisi internal dan eksternal STA maka semua populasi dijadikan responden sehingga tidak ada sampel maupun teknik sampling.

\section{Analisis Deskriptif Kualitatif}

Menurut Sugiyono (2011), analisis deskriptif adalah analisis yang mendeskripsikan atau menggambarkan objek yang diteliti melalui data sampel atau populasi, dengan tanpa membuat kesimpulan yang berlaku untuk umum dan juga memberikan gambaran yang komprehensif tentang sejarah perusahaan, situasi atau gambaran tentang perusahaan dan perkembangannya. Analisis deskriptif kualitatif digunakan untuk mengetahui gambaran umum, visi misi perusahaan, dan analisis SWOT untuk mengidentifikasi dan menganalisis faktor internal yang terdiri dari kekuatan dan kelemahan serta faktor eksternal yang terdiri dari peluang dan ancaman sehingga diperoleh gambaran secara jelas mengenai kekuatan, kelemahan, peluang, dan ancaman yang ada di STA.

\section{Analisis Deskriptif Kuantitatif}

Analisis kuantitaif adalah suatu metode penelitian yang berlandaskan pada filsafat positivisme, digunakan untuk meneliti populasi atau sampel tertentu, pengumpulan data menggunakan instrumen penelitian, analisis data bersifat

$\begin{array}{lccr}\text { RUMUSAN } & \text { STRATEGI } & \text { BISNIS SUB } \\ \text { TERMINAL } & \text { AGRIBISNIS } & \text { CIGOMBONG } \\ \text { KECAMATAN } & \text { PACET } & \text { KABUPATEN } \\ \text { CIANJUR } & & \end{array}$


kuantitatif dengan tujuan untuk menguji hipotesis yang telah ditetapkan (Sugiyono, 2015)

\section{IFE (Internal Factor Evaluation) dan EFE (External Factor Evaluation)}

Matriks IFE ditujukan untuk mengidentifikasi faktor lingkungan internal dan mengukur sejauh mana kekuatan dan kelemahan yang dimiliki perusahaan, sedangkan matriks EFE ditujukan untuk mengidentifikasi faktor lingkungan eksternal dan mengukur sejauh mana peluang dan ancaman yang dihadapi perusahaan.

\section{Matriks IE (internal-External)}

Setelah diperoleh total bobot skor rata-rata dari matriks IFE dan EFE, kemudian hasil skor dari matriks IFE dan EFE tersebut dapat digunakan untuk mengetahui posisi perusahaan melalui matriks IE.

Matriks IE memposisikan suatu organisasi dalam tampilan 9 sel. Total skor bobot IFE berada pada sumbu $\mathrm{X}$ dan total skor EFE berada pada sumbu Y. Nilai bobot pada sumbu $\mathrm{X}$ menunjukkan posisi internal (IFE) dari lemah sampai kuat dimana apabila skor bobotnya $1,00-$ 1,99 berarti berada di posisi lemah, skor bobot 2,00-2,99 rata-rata, dan skor bobot 3,00-4,00 menunjukkan kuat. Begitupun skor bobot pada sumbu $\mathrm{Y}$ yang hampir sama dengan sumbu $\mathrm{X}$, yang membedakan pada letak posisi, dimana sumbu Y menunjukkan posisi eksternal (EFE).

\section{Matriks SWOT}

Matriks SWOT merupakan alat pencocokan yang penting untuk membantu pemerintah dan stakeholders mengembangkan empat tipe strategi. Menurut Rangkuti (2014) empat tipe strategi SWOT diantaranya :

a) Strategi $S O$

Strategi yang dibuat berdasarkan jalan pikiran perusahaan yaitu dengan memanfaatkan seluruh kekuatan untuk merebut dan memanfaatkan peluang yang sebesar-besarnya.

\section{b) Strategi ST}

Merupakan strategi yang memiliki kekuatan yang dimiliki perusahaan untuk mengatasi ancaman.

c) Strategi WO

Strategi yang diterapkan berdasarkan pemanfaatan peluang yang ada dengan cara meminimalkan kelemahan yang ada.

d) Strategi WT

Strategi yang didasarkan pada kegiatan yang bersifat defensif dan berusaha meminimalkan kelemahan yang ada dan menghindari ancaman.

\section{QSPM (Quantitative Strategic Planning Matrix)}

Menurut David (2009) QSPM merupakan alat yang direkomendasikan untuk melakukan pilihan strategi alternatif secara obyektif, berdasarkan pada faktorfaktor sukses kritis eksternal dan internal yang telah diidentifikasi sebelumnya. Jadi, secara teoritis tujuan dari penggunaan QSPM adalah untuk menentukan suatu rekomendasi strategi yang dianggap paling tepat untuk diimplementasikan.

\section{HASIL DAN PEMBAHASAN}

\section{Gambaran Umum STA Cigombong}

Sub Terminal Agribisnis (STA) dan Agropolitan Kabupaten Cianjur atau yang lebih dikenal dengan STA Cigombong merupakan sarana pemasaran hasil pertanian khususnya komoditas hortikultura yang dibangun pemerintah sebagai fasilitasi bagi petani dalam rangka memberikan kemudahan maupun meningkatkan nilai tambah bagi para petani.

Setelah dibangun, STA baru diresmikan pada tahun 2004 dan pada tahun 2007 dibangun pula lokasi untuk gudang dan sortasi produk. Pada tahun 2018 tepatnya bulan Februari dibentuklah UPTD Sub Terminal Agribisnis (STA) dan Agropolitan dengan dikeluarkannya peraturan Bupati Cianjur nomor 02 tahun 2018.

Lokasi STA Cigombong sendiri secara geografis berada pada dataran

$\begin{array}{lccr}\text { RUMUSAN } & \text { STRATEGI } & \text { BISNIS } & \text { SUB } \\ \text { TERMINAL } & \text { AGRIBISNIS } & \text { CIGOMBONG } \\ \text { KECAMATAN } & \text { PACET } & \text { KABUPATEN } \\ \text { CIANJUR } & & \end{array}$


tinggi yaitu $\pm 1.100 \mathrm{M} / \mathrm{DPL}$. Terletak diantara ibukota DKI Jakarta dan Provinsi Jawa Barat. Kurang lebih 120 KM dari Jakarta dan $75 \mathrm{KM}$ dari Bandung. Adapun secara administratif, STA Cigombong berada di Kp. Cigombong, Desa Ciherang, Kecamatan Pacet, Kabupaten Cianjur.

\section{Visi dan Misi STA Cigombong} 1. Visi

Menjadi lembaga agribisnis unggulan dalam pengembangan pemasaran dan wawasan agribisnis tropika bidang pertanian dan hortikultura, melalui pendekatan sistem dan kewirausahaan untuk mendukung keberlanjutan pembangunan nasional dan meningkatkan kesejahteraan masyarakat.

\section{Misi}

1. Menyelenggarakan program tata niaga agribisnis yang bermutu dan berdaya saing tinggi dalam bidang agribisnis hortikultra serta sesuai kebutuhan masyarakat masa kini dan akan dating.

2. Mengembangkan sistem dan usaha agribisnis hortikultura yang berwawasan lingkungan melalui penelitian, penerapan ilmu bisnis dan di bidang pertanian hortikultura.

3. Mengembangkan kualitas sumber daya manusia agribisnis hortikultura untuk keberlanjutan pembangunan ekonomi nasional dan meningkatkan kesejahteraan masyarakat.

\section{Karakteristik Responden}

Karakteristik responden didapatkan melalui pengisian kuesioner oleh responden yang berjumlah 9 orang yang meliputi pengelola STA dan para pelaku usaha yang ada di STA. Dari hasil kuesioner tersebut didapatkan beberapa karakteristik responden yang terdiri dari jenis kelamin, usia, dan tingkat pendidikan.

Adapun penjabaran dari ketiga karakteristik tersebut adalah sebagai berikut.

\section{Jenis Kelamin}

Berdasarkan hasil dari kuesioner yang diberikan kepada 9 orang responden, dapat diketahui bahwa semua responden berjenis kelamin laki-laki. Hal ini dikarenakan sebagian besar para pekerja di STA berjenis kelamin laki-laki.

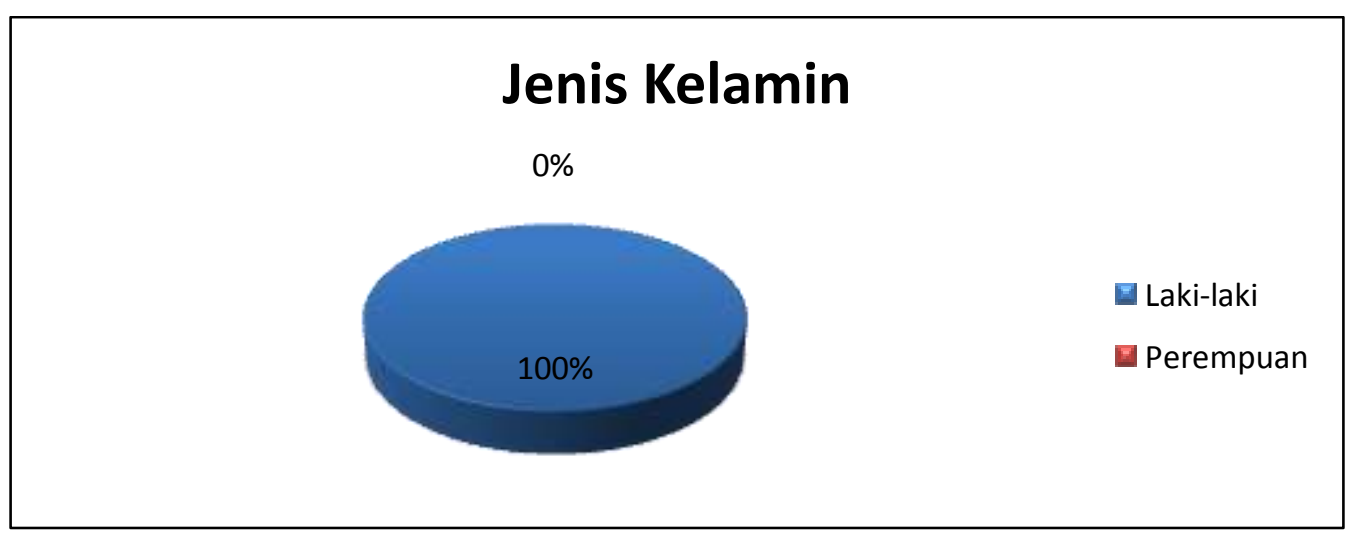

Gambar 1. Karakteristik Responden berdasarkan Jenis Kelamin Sumber: Data Primer diolah, 2020.

\section{Usia}

Jika dilihat berdasarkan usianya, sebanyak 4 orang responden berusia ratarata 20-30 tahun, 4 orang responden berusia rata-rata 31-40 tahun, dan 1 orang responden berusia rata-rata di 41-50 tahun. Menurut BPS (2020) penduduk usia tidak produktif yaitu yang berusia di bawah 15 tahun dan atau usia lebih dari 65 tahun, sedangkan penduduk usia produktif yaitu rata-rata 15-64 tahun. Dari data tersebut dapat diketahui bahwa semua responden dalam penelitian ini termasuk ke dalam usia produktif.

$\begin{array}{lccr}\text { RUMUSAN } & \text { STRATEGI } & \text { BISNIS SUB } \\ \text { TERMINAL } & \text { AGRIBISNIS } & \text { CIGOMBONG } \\ \text { KECAMATAN } & \text { PACET } & \text { KABUPATEN } \\ \text { CIANJUR } & & \end{array}$




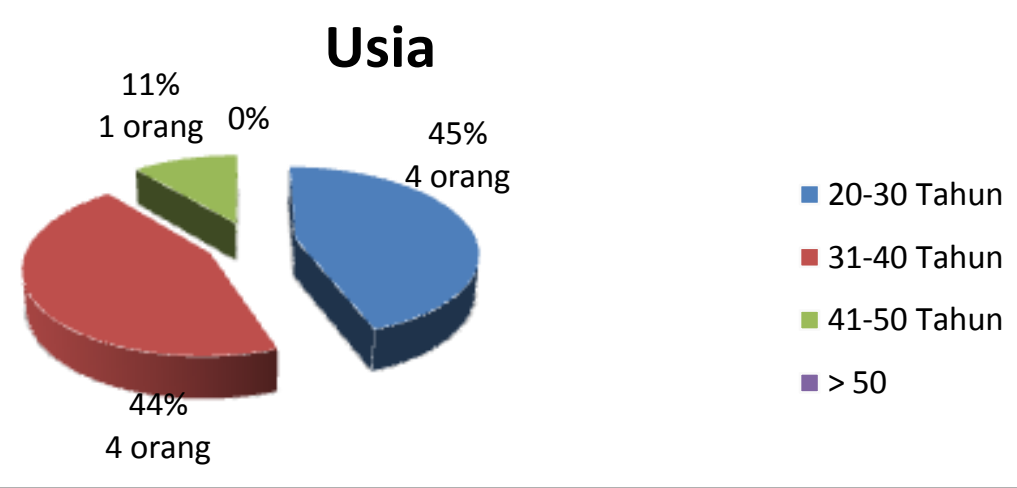

Gambar 2. Karakteristik Responden berdasarkan Usia Sumber : Data Primer Diolah, 2020.

\section{Tingkat Pendidikan}

Apabila dilihat berdasarkan tingkat pendidikannya, sebagian besar berpendidikan Sekolah Menengah Atas (SMA) yaitu sebanyak 8 orang atau $89 \%$. Adapun yang berpendidikan di perguruan tinggi 1 orang atau sekitar sebesar 11\%. Tingkat pendidikan SMA mendominasi karena para pelaku usaha berpendapat bahwa tidak harus berpendidikan tinggi tetapi dengan pengalaman yang dimiliki.

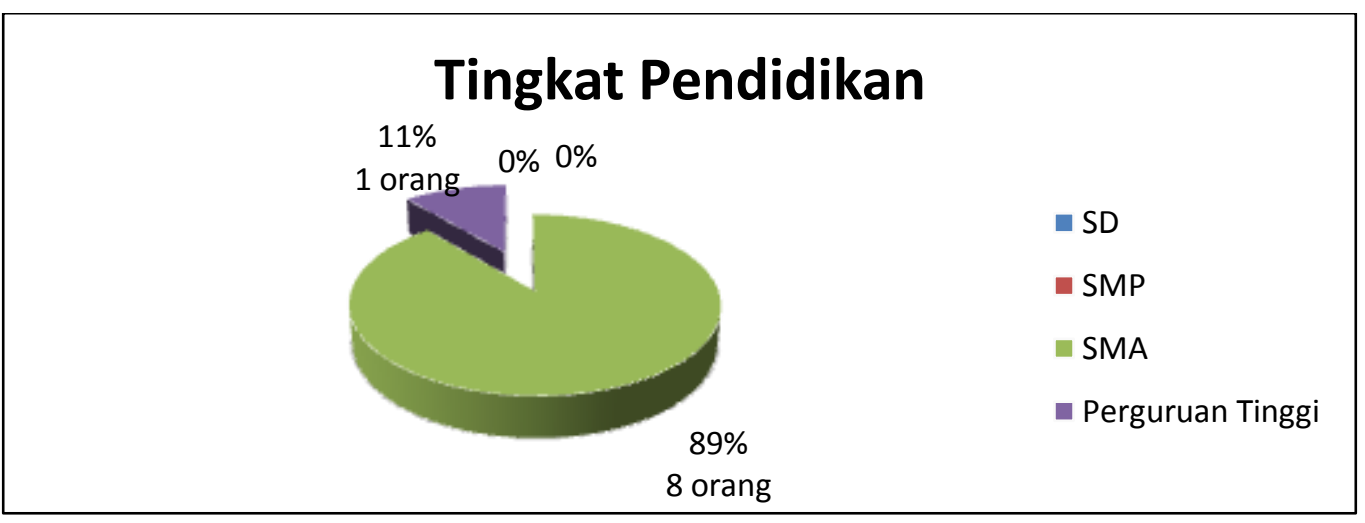

Gambar 3 Karakteristik Responden berdasarkan Tingkat Pendidikan Sumber : Data Primer Diolah, 2020

Identifikasi Faktor Internal dan Eksternal STA Cigombong

1. Faktor Internal

Berdasarkan hasil identifikasi terhadap lingkungan internal STA Cigombong, maka dapat diperoleh faktor strategi internal yaitu berupa kekuatan dan kelemahan. Adapun faktor-faktor internal yang menjadi kekuatan dan kelemahan bagi STA Cigombong tersebut diantaranya:

\section{1) Kekuatan (Strengths)}

a. Komunikasi yang terjalin antara pengelola STA dan pelaku usaha baik

$$
\text { Pengelola STA Cigombong }
$$
menjalin komunikasi yang baik dengan para pelaku yang tergabung di STA. Adanya komunikasi yang baik tersebut menjadi salah satu kekuatan bagi STA Cigombong karena komunikasi yang baik akan menghasilkan sesuatu yang baik dan juga akan berpengaruh terhadap kegiatan pemasaran sehingga dapat berjalan dengan baik dan lancar.

\section{b. Lokasi yang strategis}

STA Cigombong berada di Jl. Raya Cigombong Ciherang no. 71 Kecamatan Pacet dimana letaknya di pinggir jalan dekat dengan akses lalu lintas kendaraan sehingga mudah ditemukan. Selain itu juga dapat memudahkan bagi petani yang

$\begin{array}{lccr}\text { RUMUSAN } & \text { STRATEGI } & \text { BISNIS } & \text { SUB } \\ \text { TERMINAL } & \text { AGRIBISNIS } & \text { CIGOMBONG } \\ \text { KECAMATAN } & \text { PACET } & \text { KABUPATEN } \\ \text { CIANJUR } & & \end{array}$


bertemu dengan pelaku usaha yang tergabung dengan STA untuk melakukan transaksi serta akses masuk ke STA cukup besar sehingga memudahkan bagi kendaraan pengangkut produk hortikultura untuk masuk ke STA.

\section{c. Kualitas produk cukup baik}

Produk-produk yang tersedia di STA Cigombong memiliki kualitas yang cukup baik, karena produk-produk yang berasal dari petani tidak langsung dipasarkan melainkan dilakukan pembersihan terlebih dahulu kemudian dilakukan pula penyortiran serta pengemasan sehingga barang yang akan dipasarkan sudah dalam keadaan bersih dan baik. Hal ini dapat menjadi salah satu kekuatan bagi STA Cigombong karena dengan kualitas produk yang ada tersebut akan membuat pelanggan merasa puas dan senang.

\section{d. Ketersediaan produk}

Pengelola STA menjalin kontrak dengan petani untuk membantu petani dalam memasarkan produk pertanian, sehingga banyak petani yang memasarkan produknya melalui STA baik itu petani perorangan maupun dalam bentuk kelompok. Dengan adanya hal tersebut, petani harus memenuhi kontrak yang telah dilakukan dengan pelaku usaha di STA sehingga produk hortikultura selalu tersedia di STA.

e. Pemasaran menggunakan media sosial Dalam memasarkan produkproduk hortikultura terutama sayuran, STA Cigombong selain dengan melakukan pemasaran offline juga melakukan pemasaran secara online yaitu dengan menggunakan aplikasi whatsApp. Dengan adanya aplikasi tersebut maka konsumen dapat memesan secara online. Hal ini dapat mempermudah kegiatan pemasaran yang dilakukan.

2) Kelemahan (Weakness)

a. Struktur organisasi belum lengkap

STA Cigombong belum memiliki struktur organisasi yang lengkap dan juga belum terstruktur dengan baik yaitu pada bagian analisis usaha pertanian dan agribisnis, serta pengelolaan terminal agribisnis dan pendataan distribusi komoditi pertanian dan perkebunan. Hal ini dapat menjadi salah satu kelemahan karena dengan adanya hal tersebut, maka akan berpengaruh kepada tugas dari masing-masing bagian.

b. STA belum berperan secara maksimal

STA Cigombong belum berperan secara maksimal, terutama dalam penjualan produk belum dilakukan langsung oleh STA tetapi dilakukan oleh pelaku usaha. STA masih hanya berperan sebagai fasilitator yang menyediakan fasilitas pemasaran dan informasi harga produk hortikultura. Hal ini memang tidak bertentangan dengan bentuk STA yaitu UPTD (Unit Pelaksana Tugas Daerah) yang dalam pelaksanaannya hanya boleh menarik pajak retribusi penggunaan alat dan tempat yang dimiliki oleh dinas terkait, dalam hal ini yaitu Dinas Pertanian, Perkebunan, Pangan, dan Hortikultura.

c. Rantai pemasaran yang masih panjang Rantai pemasaran merupakan suatu jalur yang dilewati oleh barang dari produsen ke konsumen. Rantai pemasaran di STA masih panjang, hal itu dapat dilihat pada produk dari petani yang tidak bisa langsung dibeli oleh konsumen, tetapi melalui pelaku usaha yang tergabung dengan STA. Jadi rantai pemasarannya mulai dari petani kemudian dibeli oleh pelaku usaha di STA kemudian oleh pelaku usaha di STA dikirim ke pedagang besar atau pengecer atau ritel, setelah itu baru produk dipasarkan kepada konsumen. Adanya rantai pemasaran yang masih panjang tersebut dapat menyebabkan keuntungan yang diperoleh petani sedikit.

\section{Faktor Eksternal}

Berdasarkan hasil identifikasi terhadap lingkungan eksternal STA Cigombong, maka dapat diperoleh faktor strategi eksternal yaitu berupa peluang dan

$\begin{array}{lccr}\text { RUMUSAN } & \text { STRATEGI } & \text { BISNIS } & \text { SUB } \\ \text { TERMINAL } & \text { AGRIBISNIS } & \text { CIGOMBONG } \\ \text { KECAMATAN } & \text { PACET } & \text { KABUPATEN } \\ \text { CIANJUR } & & \end{array}$


ancaman. Adapun faktor-faktor eksternal yang menjadi peluang dan ancaman bagi STA Cigombong tersebut diantaranya:

\section{1) Peluang (Opportunity)}

a. Adanya dukungan dari pemerintah STA Cigombong mendapat dukungan ddari pemerintah. Dukungan dari pemerintah ini yaitu dengan dikeluarkannya peraturan Bupati Cianjur Nomor 02 Tahun 2018. Adanya dukungan ini dapat menjadi salah satu peluang bagi STA, dimana Perbup ini membuat pengelolaan STA menjadi di bawah Dinas Pertanian, Perkebunan, Pangan, dan Hortikultura, sehingga bantuan-bantuan dari pemerintah dapat secara tepat disalurkan kepada petani yang memasok sayuran ke STA.

a. Perubahan gaya hidup sehat masyarakat Adanya perubahan gaya hidup sehat masyarakat juga dapat menjadi peluang bagi STA Cigombong karena kesadaran masyarakat akan pentingnya hidup sehat dan pola makan yang sesuai dengan gizi seimbang maka akan berpengaruh terhadap permintaan sayuran yang meningkat. Hal ini berkaitan dengan banyaknya masyarakat yang menjadi vegetarian dan melakukan diet seimbang. Selain itu, pada saat penelitian ini dilakukan bertepatan dengan sedang terjadinya pandemi covid yang menyebabkan masyarakat mulai membiasakan hidup lebih sehat sesuai dengan anjuran pemerintah melalui gerakan masyarakat hidup sehat dalam padan gizi seimbang pada masa covid-19.

b. Adanya permintaan produk dari konsumen

Adanya peluang permintaan produk sesuai dengan kontrak yang telah dilakukan oleh pelaku usaha dengan pedagang besar atau pengecer atau ritel ini dapat dimanfaatkan oleh STA agar dapat meningkatkan pendapatan pelaku usaha atau petani dan agar permintaan produk dari konsumen dapat terpenuhi maka STA perlu menjaga ketersediaan agar produk selalu tersedia yaitu dengan cara bermitra dengan pemasok-pemasok lainnya diluar kabupaten Cianjur apabila sayuran yang diminta tidak diproduksi oleh petani di Cianjur.

c. Perluasan pasar

Adanya perluasan pasar dapat dimanfaatkan oleh STA Cigombong agar dapat menjual produk ke kota-kota lain, sebab saat ini pelaku usaha di STA Cigombong baru memasarkan sayurannya ke jakarta, Bogor, dan Cibubur. Kemudian lebih rutin lagi dalam melakukan ekspor ke luar negeri sehingga dapat dikenal dan pendapatanpun bisa meningkat.

d. Berkembangnya teknologi, informasi, dan komunikasi

$$
\text { Berkembangnya teknologi, }
$$

informasi, dan komunikasi dapat memperkecil jarak dalam dunia bisnis. Setiap informasi-informasi dapat lebih mudah diakses melalui internet. Berbagai alat komunikasi yang ada dapat menjadi sarana pembelian, pembayaran, dan pemasaran bagi setiap pelaku usaha, begitupun bagi STA apabila STA dapat mengikuti perkembangan teknologi tersebut maka hal tersebut dapat memudahkan STA baik dalam hal informasi maupun dalam kegiatan pemasarannya. Sehingga perkembangan teknologi tersebut dapat menjadi salah satu peluang bagi STA Cigombong. Mengingat saat ini STA baru melakukan penyebaran informasi harga sayuran dengan menggunakan $L E D$ yang terdapat di gerbang masuk STA yang diperbarui setiap hari. Selain itu, pemasaran produk sayuran juga dilakukan melalui WhatsApp.

\section{2) Ancaman (Threats)}

a. Berkurangnya lahan pertanian karena alih fungsi lahan

Lahan pertanian semakin berkurang karena banyaknya lahan yang dialihfungsikan sebagai bangunanbangunan seperti perumahan, restoran, dan bangunan untuk keperluan perindustrian. Jika lahan pertanian semakin berkurang maka akan berakibat pada produksi yang menurun. Apabila

$\begin{array}{lccr}\text { RUMUSAN } & \text { STRATEGI } & \text { BISNIS SUB } \\ \text { TERMINAL } & \text { AGRIBISNIS } & \text { CIGOMBONG } \\ \text { KECAMATAN } & \text { PACET } & \text { KABUPATEN } \\ \text { CIANJUR } & & \end{array}$


produksi menurun maka jumlah produk yang dihasilkan akan berkurang sehingga hal tersebut dapat menjadi ancaman terhadap ketersediaan produk.

b. Rendahnya hambatan masuk bagi pesaing baru

Rendahnya hambatan menjadi peluang yang dapat dimanfaatkan oleh para pesaing baru untuk masuk ke dalam bidang yang sama, mengingat banyaknya petani kecil yang menanam berbagai komoditas hortikultura. Namun bagi STA hal tersebut dapat menjadi suatu ancaman karena dengan begitu persaingan akan semakin ketat.

\section{Perumusan Strategi}

Untuk menjawab tujuan penelitian kedua, dilakukan analisis matriks IFE, EFE, dan QSPM yang terbagi ke dalam beberapa tahap perumusan strategi. Adapun tahap-tahap perumusan strategi tersebut adalah sebagai berikut.

\section{Tahap Masukan (Input)}

Tahap masukan ini merupakan tahap awal dalam perumusan strategi. Analisis yang digunakan yaitu matriks IFE dan matriks EFE.

(1) Analisis Matriks IFE (Internal Factor Evaluation)
Analisis lingkungan internal dilakukan dengan meninjau faktor-faktor yang menjadi kekuatan dan kelemahan yang kemudian akan didapatkan bobot rata-rata dari masing-masing faktor internal. Jadi, setelah diperoleh faktorfaktor internal STA Cigombong yang meliputi kekuatan dan kelemahan, kemudian dilanjutkan dengan pemberian kuesioner kepada 9 responden. Kuesioner diisi oleh masing-masing responden untuk memperoleh nilai pembobotan dengan menggunakan paired comparison matrix dan rating untuk masing-masing variabel kekuatan dan kelemahan. Setelah diperoleh nilai pembobotan dan rating dari masing-masing responden, selanjutnya pencarian bobot rata-rata dan rating rata-rata dari seluruh responden dengan cara membagi hasil penjumlahan seluruh nilai bobot atau rating dari seluruh responden untuk masing-masing variabel kekuatan dan kelemahan dengan jumlah responden yaitu 9 responden.

Setelah diperoleh bobot rata-rata dan rating rata-rata, kemudian dilanjutkan dengan pencarian skor rata-rata. Skor rata-rata didapatkan dari hasil perkalian antara bobot rata-rata dengan rating ratarata. Untuk lebih jelasnya dapat dilihat pada tabel matriks IFE berikut ini.

Tabel 2. Analisis Matriks IFE STA Cigombong.

\begin{tabular}{|c|c|c|c|}
\hline Faktor-Faktor Internal & $\begin{array}{c}\text { Bobot Rata- } \\
\text { Rata }\end{array}$ & $\begin{array}{c}\text { Rating Rata- } \\
\text { Rata }\end{array}$ & $\begin{array}{c}\text { Skor } \\
\text { Bobot }\end{array}$ \\
\hline \multicolumn{4}{|c|}{ Kekuatan } \\
\hline $\begin{array}{l}\text { Komunikasi yang terjalin antara pengelola dan } \\
\text { pelaku usaha baik }\end{array}$ & 0,12 & 4,0 & 0,48 \\
\hline Lokasi yang strategis & 0,13 & 4,0 & 0,50 \\
\hline Kualitas produk cukup baik & 0,15 & 3,8 & 0,58 \\
\hline Ketersediaan produk & 0,15 & 3,8 & 0,56 \\
\hline Pemasaran menggunakan media sosial & 0,11 & 3,3 & 0,37 \\
\hline Jumlah & & & 2,49 \\
\hline \multicolumn{4}{|c|}{ Kelemahan } \\
\hline Struktur Organisasi belum lengkap & 0,12 & 2,0 & 0,23 \\
\hline STA belum berperan secara maksimal & 0,11 & 1,8 & 0,20 \\
\hline Rantai pemasaran yang masih panjang & 0,12 & 1,0 & 0,12 \\
\hline \multicolumn{3}{|l|}{$\begin{array}{ll}\text { Jumlah } \\
\end{array}$} & 0,55 \\
\hline Jumlah Total Skor & 1,00 & & 3,03 \\
\hline
\end{tabular}

Sumber : Data Primer Diolah, 2020.

$\begin{array}{lccr}\text { RUMUSAN } & \text { STRATEGI } & \text { BISNIS } & \text { SUB } \\ \text { TERMINAL } & \text { AGRIBISNIS } & \text { CIGOMBONG } \\ \text { KECAMATAN } & \text { PACET } & \text { KABUPATEN } \\ \text { CIANJUR } & & \end{array}$


Dari tabel di atas dapat diketahui bahwa yang memiliki skor bobot rata-rata terbesar yang berarti menjadi kekuatan utama bagi STA Cigombong adalah kualitas produk cukup baik dengan skor bobot 0,58. Tingginya skor bobot yang terdapat pada variabel tersebut karena produk-produk yang ada di STA Cigombong selalu diberikan perlakuan seperti pembersihan, penyortiran, maupun dalam pengemasan dilakukan dengan baik sehingga produk baik dan bagus. Kelemahan utama yang dimiliki STA Cigombong yaitu rantai pemasaran yang masih panjang dengan skor bobot sebesar 0,12. Produk-produk yang ada di STA Cigombong tidak bisa langsung dibeli oleh konsumen tetapi melalui pelaku usaha terlebih dahulu sehingga rantai pemasarannya masih panjang.

Secara keseluruhan total skor ratarata tertimbang matriks IFE yaitu sebesar 3,03 yang mengindikasikan bahwa STA Cigombong berada di atas 2,5 dari keseluruhan kekuatan internalnya. Jadi, dapat dikatakan bahwa STA Cigombong memiliki respon internal yang kuat atau cukup mampu menggunakan kekuatan

yang dimiliki untuk meminimalisir kelemahan yang dimiliki.

\section{Matriks EFE (External Factor Evaluation)}

Analisis matriks EFE digunakan untuk mengatasi ancaman dengan memanfaatkan peluang yang ada. Setelah diperoleh faktor-faktor eksternal STA Cigombong yang meliputi peluang dan ancaman, kemudian dilanjutkan dengan pemberian kuesioner kepada 9 responden seperti halnya pemberian kuesioner pada faktor-faktor internal. Kuesioner diisi oleh masing-masing responden untuk memperoleh nilai pembobotan dengan menggunakan paired comparison matrix dan rating untuk masing-masing variabel peluang dan ancaman. Setelah diperoleh nilai pembobotan dan rating dari masingmasing responden, selanjutnya pencarian bobot rata-rata dan rating rata-rata dari seluruh responden dengan cara membagi hasil penjumlahan seluruh nilai bobot atau rating dari seluruh responden untuk masing-masing variabel peluang dan ancaman dengan jumlah responden yaitu 9 .

Tabel 3. Analisis Matriks EFE STA Cigombong

\begin{tabular}{|c|c|c|c|}
\hline Faktor-Faktor Eksternal & $\begin{array}{l}\text { Bobot Rata- } \\
\text { Rata }\end{array}$ & $\begin{array}{l}\text { Rating Rata- } \\
\text { Rata }\end{array}$ & $\begin{array}{c}\text { Skor } \\
\text { Bobot }\end{array}$ \\
\hline \multicolumn{4}{|c|}{ Peluang } \\
\hline Adanya dukungan dari pemerintah & 0,15 & 3,0 & 0,46 \\
\hline Perubahan gaya hidup sehat masyarakat & 0,12 & 2,6 & 0,31 \\
\hline Adanya permintaan produk dari konsumen & 0,18 & 3,0 & 0,53 \\
\hline Perluasan pasar & 0,16 & 2,6 & 0,42 \\
\hline $\begin{array}{l}\text { Berkembangnya teknologi, informasi, dan } \\
\text { komunikasi }\end{array}$ & 0,12 & 3,0 & 0,37 \\
\hline Jumlah & & & 2,09 \\
\hline \multicolumn{4}{|c|}{$\begin{array}{ll} & \text { Ancaman } \\
\end{array}$} \\
\hline $\begin{array}{l}\text { Berkurangnya lahan pertanian karena alih fungsi } \\
\text { lahan }\end{array}$ & 0,16 & 3,0 & 0,47 \\
\hline Rendahnya hambatan masuk bagi pesaing baru & 0,11 & 2,6 & 0,27 \\
\hline Jumlah & & & 0,74 \\
\hline Jumlah Total Skor & 1,00 & & 2,83 \\
\hline
\end{tabular}

Sumber : Data Primer diolah, 2020.

Dari tabel matriks EFE diatas dapat dilihat bahwa peluang utama bagi STA Cigombong adalah adanya permintaan produk dari konsumen dengan skor rata-rata sebesar 0,53. Tingginya skor bobot pada variabel tersebut karena STA memiliki produk yang berkualitas sehingga selalu adanya 
permintaan dari konsumen. Adapun ancaman utama bagi STA Cigombong yaitu variabel ancaman yang memiliki skor rata-rata terkecil. Variabel ancaman dengan skor terkecil yaitu rendahnya hambatan masuk bagi pesaing baru dengan skor rata-rata 0,27 .

Adapun total skor rata-rata tertimbang dari matriks EFE yaitu sebesar 2,83 yang mengindikasikan bahwa STA Cigombong berada di atas 2,5 atau di sekitar rata-rata $(2,0-2,99)$ yang berarti posisi eksternal sedang dalam upaya untuk memanfaatkan peluang dan menghindari ancaman.

\section{Tahap Pencocokan}

Tahap pencocokan merupakan tahap lanjutan dari tahap masukan. Analisis yang digunakan yaitu matriks IE (Internal-External) dan matriks SWOT.

\section{Matriks IE (Internal - External)}

Tahap selanjutnya dalam menentukan alternatif strategi yaitu dengan melalui matriks IE. Setelah diperoleh total skor bobot rata-rata dari matriks IFE yaitu sebesar 3,03 dan matriks EFE sebesar 2,83, kemudian hasil skor tersebut dapat digunakan untuk mengetahui posisi perusahaan. Berikut ini merupakan hasil matriks IE pada STA Cigombong yang dapat dilihat pada gambar 4 berikut.

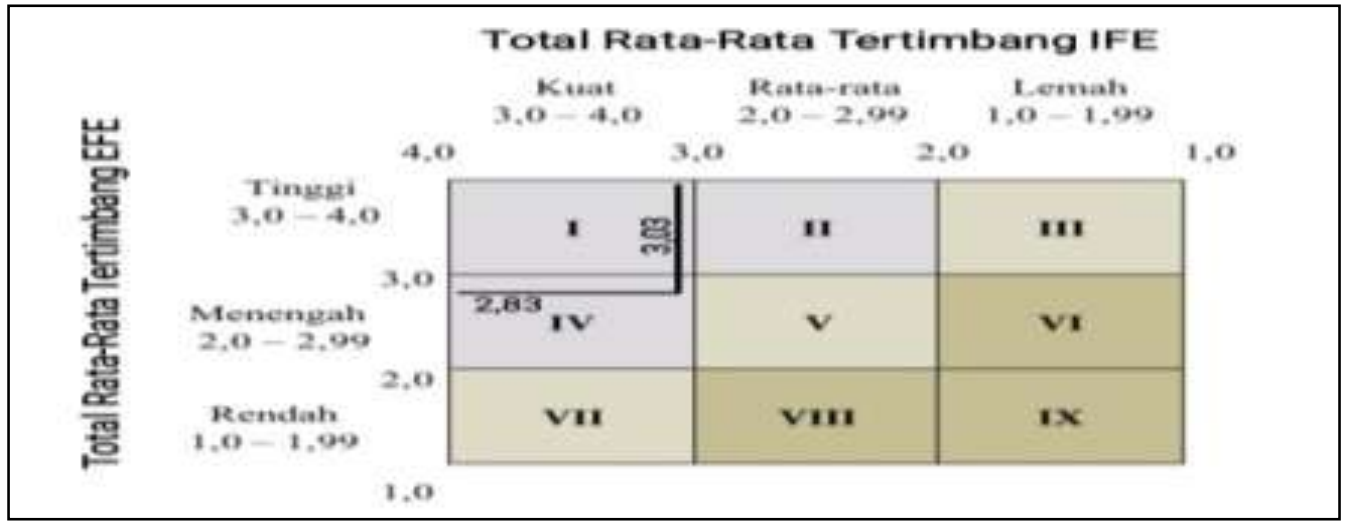

Gambar 4. Matriks IE STA Cigombong

Sumber : Data Primer Diolah, 2020.

Dari gambar 4 dapat dilihat bahwa posisi STA Cigombong berada pada kuadran IV yang berarti tumbuh dan kembangkan, yaitu dimana memiliki kemampuan internal yang kuat dan memiliki kemampuan eksternal yang sedang. Dalam hal ini STA paling baik dikendalikan dengan strategi tumbuh dan kembangkan (Grow and Build), adapun strategi yang dapat diterapkan apabila dilihat dari matriks IE di atas yaitu strategi intensif yang meliputi penetrasi pasar, pengembangan pasar, dan pengembangan produk. Penetrasi pasar adalah mencari pangsa pasar yang lebih besar dari produk yang telah ada saat ini dengan melalui usaha pemasaran lebih gencar. Pengembangan produk yaitu mencoba mencoba meningkatkan penjualan dengan memperbaiki produk yang sudah ada.

\section{1) Analisis Matriks SWOT}

Dalam analisis matriks SWOT ini terdapat empat strategi utama yang disarankan yaitu strategi SO (Strength and Opportunity), strategi WO (Weakness and Opportunity), strategi ST (Strength and Threat), dan strategi WT (Weakness and Threats). Adapun hasil analisis matriks SWOT STA Cigombong terdapat pada tabel 4 .

$\begin{array}{lccr}\text { RUMUSAN } & \text { STRATEGI } & \text { BISNIS } & \text { SUB } \\ \text { TERMINAL } & \text { AGRIBISNIS } & \text { CIGOMBONG } \\ \text { KECAMATAN } & \text { PACET } & \text { KABUPATEN } \\ \text { CIANJUR } & & \end{array}$


Tabel 4. Matriks SWOT STA Cigombong

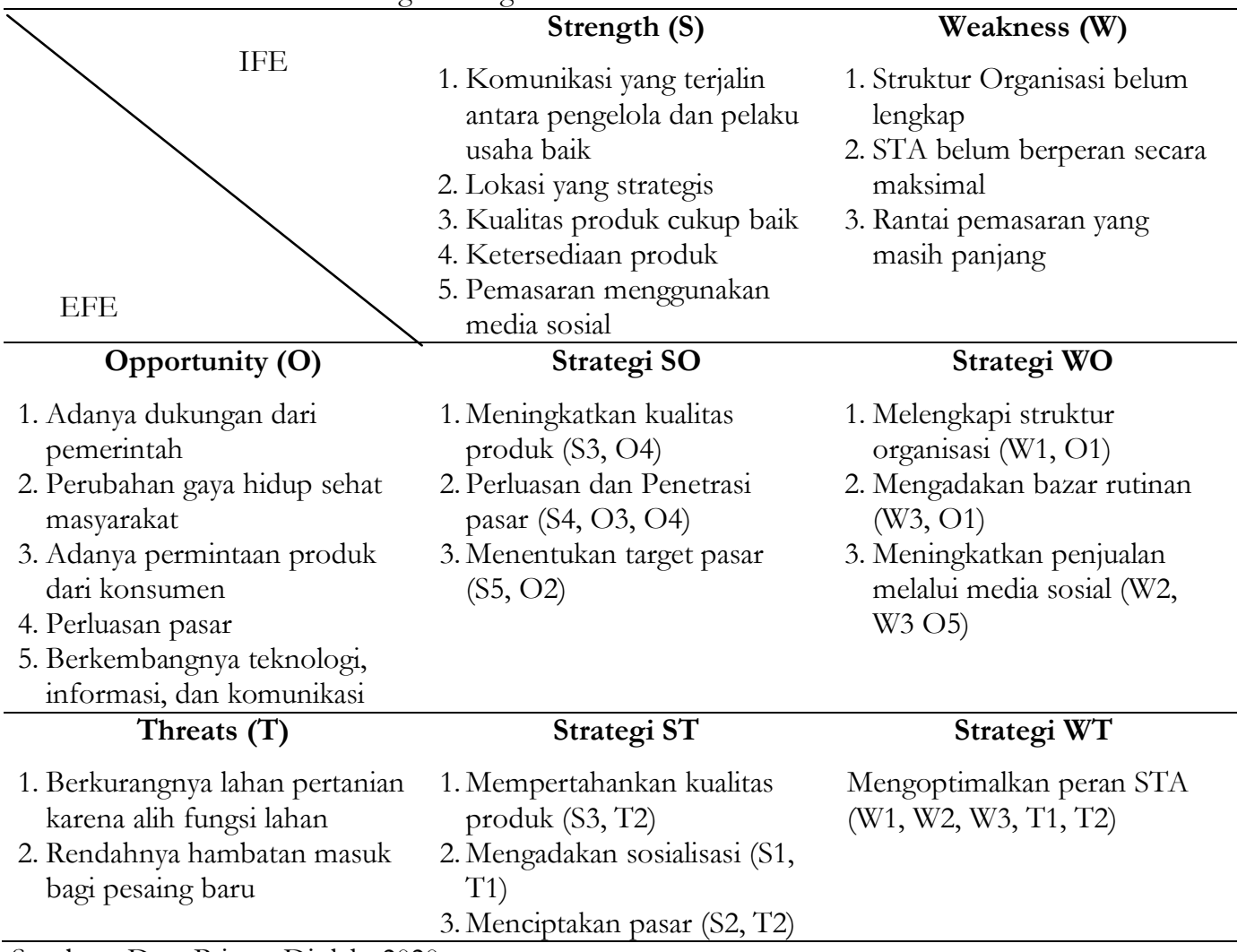

Sumber : Data Primer Diolah, 2020.

Berdasarkan analisis matriks SWOT, maka alternatif atau pilihan strategi yang dapat diberikan untuk STA Cigombong adalah sebagai berikut.

\section{Strategi SO (Strength and Opportunity)}

Strategi SO merupakan strategi yang menggunakan kekuatan dengan memanfaatkan peluang.

1) Meningkatkan kualitas produk (S3, O4)

Produk yang berkualitas baik akan dicari oleh konsumen, untuk itu STA Cigombong perlu meningkatkan kualitas produknya. Meningkatkan kualitas produk ini selain agar dapat bersaing dengan perusahaan-perusahaan sayuran lain juga agar STA Cigombong dapat memperluas pasarnya dengan memasarkan produk ke beberapa daerah lain. Adapun dalam meningkatkan kualitas produknya dapat dilakukan STA Cigombong dengan cara memberikan perlakuan yang terbaik dari mulai pembersihan sampai dengan pengemasan, selalu menyediakan produk yang unggul dan selalu memperhatikan agar kualitas produk bisa terjaga sampai kepada konsumen.

\section{2) Perluasan dan penetrasi pasar ( $\mathrm{S} 4$, O3, 04)}

Strategi ini direkomendasikan dengan memanfaatkan kekuatan yang dimiliki STA Cigombong yaitu ketersediaan produk. Dengan adanya ketersediaan produk di STA Cigombong, maka STA dapat memperluas pemasarannya ke berbagai tempat-tempat lain, sehingga tidak hanya terpaku pada tempat tujuan yang sudah ada saja. Selain itu dengan adanya peluang permintaan konsumen, maka STA dapat menjangkau konsumen dimana pun dengan ketersediaan produk yang dimiliki.

\section{3) Menentukan target pasar (S5, O2)}

Kesadaran masyarakat akan pentingnya hidup sehat dan pola makan yang sesuai dengan gizi seimbang menjadikan adanya perubahan terhadap

$\begin{array}{lccr}\text { RUMUSAN } & \text { STRATEGI } & \text { BISNIS SUB } \\ \text { TERMINAL } & \text { AGRIBISNIS } & \text { CIGOMBONG } \\ \text { KECAMATAN } & \text { PACET } & \text { KABUPATEN } \\ \text { CIANJUR } & & \end{array}$


gaya hidup masyarakat itu sendiri. Adanya perubahan gaya hidup sehat masyarakat dapat dimanfaatkan dalam membentuk strategi dengan menggunakan kekuatan yang dimiliki yaitu pemasaran melalui media sosial (online). Strategi yang direkomendasikan yaitu menentukan target pasar. Jadi, dengan adanya pemasaran online maka dapat memudahkan dalam menarik konsumen terutama konsumen vegetarian ataupun konsumen yang baru menerapkan gaya hidup sehat.

\section{Strategi WO (Weakness and Opportunity)}

Strategi WO yaitu strategi yang meminimalkan kelemahan untuk memanfaatkan peluang yang ada.

1) Melengkapi struktur organisasi (W1, O1)

STA Cigombong belum memiliki struktur organisasi yang lengkap, untuk itu STA Cigombong perlu melengkapi struktur organisasi. Dengan adanya dukungan dari pemerintah, maka Dinas Pertanian, Perkebunan, Pangan, dan Hortikultura dapat membantu dalam menambah jumlah rekrut untuk merekrut tenaga kerja untuk mengisi bagian yang kosong dalam struktur organisasi STA sehingga struktur organisasi STA Cigombong lengkap dan setiap bagian memiliki tugasnya masing-masing dan jelas. Struktur yang lengkap ini akan lebih memfasilitasi petani dalam mendapatkan layanan dari STA Cigombong.

2) Mengadakan bazar rutinan (W3, O1)

Saat ini rantai pemasaran di STA Cigombong masih panjang, untuk itu perlu adanya strategi yang dapat memperpendek rantai pemasaran. Adapun strategi yang bisa diterapkan yaitu mengadakan bazar rutinan yang di dukung oleh pemerintah misalnya dengan memberikan fasilitas. Bazar rutinan ini dapat dilakukan misalnya dengan mengadakan bazar seminggu sekali, sehingga dapat mempertemukan langsung antara STA dengan konsumen, dan dapat memperpendek rantai pemasaran.
3) Meningkatkan penjualan melalui media sosial (W2, W3, O5)

Dengan memanfaatkan peluang berkembangnya teknologi, informasi, dan komunikasi, STA Cigombong dapat menerapkan strategi meningkatkan penjualan melalui media sosial. Meningkatkan penjualan melalui media sosial ini dapat dilakukan dengan cara memberikan sesuatu yang menarik seperti promosi, informasi yang menarik dan mudah dipahami oleh konsumen, aktif di media sosial. Adanya strategi ini diharapkan agar penjualan menjadi meningkat dan juga dapat dilakukan langsung oleh STA sehingga STA dapat berperan maksimal dan rantai pemasaran juga dapat diperpendek.

\section{Strategi ST (Strength and Threats)}

Strategi ST yaitu strategi yang menggunakan kekuatan untuk mengatasi ancaman yang ada.

1) Mempertahankan kualitas produk (S3, T2)

STA Cigombong memiliki kualitas produk yang baik, dengan adanya kualitas produk yang baik tersebut diharapkan STA Cigombong tetap dapat mempertahankan kualitas produknya. Dengan mempertahankan kualitas produk maka diharapkan dapat meminimalisir ancaman adanya pesaing baru.

\section{2) Mengadakan sosialisasi (S1, T1)}

Kekuatan yang dimiliki STA Cigombong dalam strategi ini yaitu adanya komunikasi yang baik antara STA dengan pelaku usaha maupun petani. Adanya hubungan baik yang terjalin tersebut maka dapat mempermudah dalam mengadakan sosialisasi tentang alih fungsi lahan yang dapat menyebabkan lahan pertanian berkurang. Dengan adanya sosialisasi ini diharapkan dapat meminimalisir dan mengatasi ancaman terkait dengan alih fungsi lahan.

\section{3) Menciptakan Pasar (S3, T2)}

Strategi ini direkomendasikan sebagai tanggapan atas kekuatan yang dimiliki STA Cigombong yaitu lokasi yang

$\begin{array}{lccr}\text { RUMUSAN } & \text { STRATEGI } & \text { BISNIS } & \text { SUB } \\ \text { TERMINAL } & \text { AGRIBISNIS } & \text { CIGOMBONG } \\ \text { KECAMATAN } & \text { PACET } & \text { KABUPATEN } \\ \text { CIANJUR } & & \end{array}$


strategis, serta ancaman yang dihadapi STA Cigombong yaitu rendahnya hambatan masuk bagi pesaing baru. Dengan menciptakan pasar, diharapkan dapat meminimalisir dan mengatasi ancaman tentang rendahnya hambatan masuk bagi pesaing baru.

\section{Strategi WT (Weakness and Threats)}

Strategi WT yaitu strategi yang berusaha meminimalkan kelemahan yang ada dan menghindari ancaman.

\section{1) Mengoptimalkan peran STA (W1,} W2, W3, T1, T2)

Dengan berbagai kelemahan yang ada dan berbagai ancaman yang dihadapi, STA Cigombong harus mengoptimalkan perannya yaitu sebagai lembaga pemasaran yang membantu para petani dalam memasarkan produknya. Adapun cara STA Cigombong dalam mengoptimalkan perannya dapat dilakukan misalnya dengan cara memutus atau memperpendek rantai pemasaran yang masih panjang, mempertemukan langsung petani dengan konsumen, mengadakan pembinaan atau pelatihan terhadap petani-petani pemasok agar pengetahuannya meningkat.

\section{Tahap Keputusan}

Setelah melewati tahap masukan dengan matriks IFE dan EFE serta tahap pencocokan dengan matriks IE dan matriks SWOT, tahap akhir atau tahap keputusan dalam perumusan strategi yaitu merumuskan strategi yang direkomendasikan. Adapun alat analisis yang digunakan pada tahap keputusan ini yaitu matriks perencanaan strategi kuantitatif (Quantitative Strategic Planning Matriks) atau QSPM.

QSPM ini didapatkan dari hasil perumusan strategi pada tahap masukan dan pencocokan untuk dapat menemukan alternatif strategi yang diprioritaskan. Untuk mengetahui alternatif strategi yang diprioritaskan dilakukan dengan memberikan kuesioner kepada responden yang kemudian dari kuesioner tersebut diperoleh nilai AS (Attractiviness score) yang menunjukkan daya tarik masingmasing strategi terhadap faktor kunci internal dan eksternal. Dari nilai AS tersebut kemudian dilanjutkan dengan pencarian nilai TAS (Total attractiviness score) dengan mengkalikan bobot ratarata dan nilai AS dari setiap faktor kunci strategi. Setelah mendapatkan nilai TAS, kemudian dilakukan perhitungan nilai STAS (Sum Total attractiviness score) dari masing-masing responden dengan cara menjumlahkan seluruh nilai TAS dari masing-masing faktor internal dan eksternal. Setelah diperoleh nilai STAS dari masing-masing responden, selanjutnya dilanjutkan dengan perhitungan STAS rata-rata dari seluruh responden dengan cara membagi hasil penjumlahan STAS seluruh responden dengan jumlah responden yang ada. Adapun hasil perhitungan rata-rata STAS untuk melihat prioritas strategi di STA Cigombong dapat dilihat pada tabel berikut.

$\begin{array}{lccr}\text { RUMUSAN } & \text { STRATEGI } & \text { BISNIS } & \text { SUB } \\ \text { TERMINAL } & \text { AGRIBISNIS } & \text { CIGOMBONG } \\ \text { KECAMATAN } & \text { PACET } & \text { KABUPATEN } \\ \text { CIANJUR } & & \end{array}$


Tabel 5. Prioritas Alternatif Strategi pada Sub Terminal Agribisnis (STA) Cigombong.

\begin{tabular}{|c|c|c|c|c|c|c|}
\hline \multirow{2}{*}{$\begin{array}{l}\text { Alternatif } \\
\text { Strategi }\end{array}$} & \multicolumn{4}{|c|}{ Responden } & \multirow{2}{*}{ Rata-rata } & \multirow{2}{*}{$\begin{array}{l}\text { Prioritas } \\
\text { Strategi }\end{array}$} \\
\hline & 1 & 2 & 3 & 4 & & \\
\hline STAS 1 & 102,89 & 102,89 & 102,89 & 102,89 & 102,89 & 1 \\
\hline STAS 2 & 77,17 & 77,17 & 77,17 & 77,17 & 77,17 & 5 \\
\hline STAS 3 & 51,45 & 51,45 & 25,72 & 77,17 & 51,45 & 8 \\
\hline STAS 4 & 102,89 & 102,89 & 77,17 & 102,89 & 96,46 & 2 \\
\hline STAS 5 & 102,89 & 77,17 & 77,17 & 77,17 & 83,60 & 4 \\
\hline STAS 6 & 77,17 & 77,17 & 51,45 & 77,17 & 70,74 & 6 \\
\hline STAS 7 & 102,89 & 77,17 & 102,89 & 77,17 & 90,03 & 3 \\
\hline STAS 8 & 77,17 & 77,17 & 51,45 & 102,89 & 77,17 & 5 \\
\hline STAS 9 & 77,17 & 51,45 & 51,45 & 77,17 & 64,31 & 7 \\
\hline STAS 10 & 102,89 & 102,89 & 102,89 & 102,89 & 102,89 & 1 \\
\hline
\end{tabular}

Sumber : Data Primer Diolah, 2020.

Dari tabel 5. di atas dapat dilihat bahwa prioritas strategi yang utama yaitu strategi yang memiliki skor lebih tinggi dari alternatif strategi lainnya yaitu meningkatkan kualitas produk dan mengoptimalkan peran STA dengan ratarata STAS sama yaitu sebesar 102,89. Adapun urutan prioritas strategi yang direkomendasikan di STA Cigombong adalah sebagai berikut.

(1) Meningkatkan kualitas produk (STAS $=102,89)$ dan mengoptimalkan peran STA $($ STAS $=102,89)$

(2) Melengkapi struktur organisasi (STAS $=96,46$ )

(3) Mempertahankan kualitas produk $($ STAS $=90,03)$

(4) Mengadakan bazar rutinan (STAS = $83,60)$

(5) Perluasan dan penetrasi pasar (STAS = $77,17)$ dan mengadakan sosialisasi $($ STAS $=77,17)$

(6) Meningkatkan penjualan melalui media sosial $($ STAS $=70,74)$

(7) Menciptakan pasar (STAS $=64,31$ )

(8) Menentukan target pasar (STAS = $51,45)$

Berdasarkan hasil QSPM di atas apabila dikaitkan dengan matriks IE (Internal - External) yang dapat simpulkan bahwa internal lebih kuat maka dapat dikatakan bahwa hasil yang didapatkan sudah sinkron atau sesuai karena dilihat dari hasil QSPM pun lebih kuat

$\begin{array}{lccr}\text { RUMUSAN } & \text { STRATEGI } & \text { BISNIS } & \text { SUB } \\ \text { TERMINAL } & \text { AGRIBISNIS } & \text { CIGOMBONG } \\ \text { KECAMATAN } & \text { PACET } & \text { KABUPATEN } \\ \text { CIANJUR } & & \end{array}$

internalnya. Hal ini dapat dibuktikan dengan melihat dari alternatif strateginya dimana yang menjadi prioritas strategi yaitu 1, 2, dan 3 ada pada internal. Sedangkan strategi yang lainnya termasuk ke dalam eksternal. Karena faktor internal yang lebih mendominasi, maka STA dapat mengutamakan internalnya. Adapun yang termasuk internal yaitu:

1. Meningkatkan kualitas produk dan mengoptimalkan peran STA.

2. Melengkapi struktur organisasi.

3. Mempertahankan kualitas produk.

\section{KESIMPULAN}

Kesimpulan dari penelitian yang telah disusun dan dipaparkan dalam pembahasan, terdapat beberapa kesimpulan sebagai berikut.

1. Faktor internal dan faktor eksternal yang dapat mempengaruhi kebijakan strategi STA Cigombong di antaranya:

a. Faktor Internal kekuatan yang terdiri dari:

1) Komunikasi yang terjalin antara pengelola dan pelaku usaha baik

2) Lokasi yang strategis

3) Kualitas produk cukup baik

4) Ketersediaan produk

5) Pemasaran menggunakan media sosial

b.Faktor Internal kelemahan terdiri dari: 
1) Struktur organisasi belum lengkap

2) STA belum berperan secara maksimal

3) Rantai pemasaran yang masih panjang

c. Faktor eksternal peluang terdiri dari:

1) Adanya dukungan dari pemerintah

2) Perubahan gaya hidup sehat masyarakat

3) Adanya permintaan produk dari konsumen

4) Perluasan pasar

5) Berkembangnya teknologi, informasi, dan komunikasi

d. Faktor Eksternal ancaman terdiri dari:

1) Berkurangnya lahan pertanian karena alih fungsi lahan

2) Rendahnya hambatan masuk bagi pesaing baru

2. Berdasarkan hasil analisis SWOT yang terdiri dari kekuatan, kelemahan, peluang, dan ancaman, menghasilkan sebelas strategi. Adapun urutan prioritas strategi yang direkomendasikan dengan menggunakan matriks QSPM adalah sebagai berikut.

(1) Meningkatkan kualitas produk dan mengoptimalkan peran STA

(2) Melengkapi struktur organisasi

(3) Mempertahankan kualitas produk

(4) Mengadakan bazar rutinan

(5) Perluasan dan penetrasi pasar dan mengadakan sosialisasi

(6) Meningkatkan penjualan melalui media sosial

(7) Menciptakan pasar

(8) Menentukan target pasar

Dari sebelas strategi yang direkomendasikan tersebut, prioritas strategi yang memiliki skor lebih tinggi dan menjadi prioritas utama dari alternatif strategi lainnya yaitu meningkatkan kualitas dan mengoptimalkan peran STA dengan skor rata-rata STAS (Sum Total Attractiveness Score) sebesar 102,89.

\section{DAFTAR PUSTAKA}

Anugrah, Iwan Setiajie. 2004. Pengembangan Sub Terminal Agribisnis (STA) dan Pasar Lelang Komoditas Pertanian Dan Permasalahannya. Ejurnal Pusat Penelitian dan Pengembangan Sosial Ekonomi Pertanian. Bogor. 22 (2): 102-112.

Arikunto, Suharsimi. 2010. Prosedur Penelitian Suatu Pendekatan Praktik. Jakarta: PT. Rineka Cipta.

Badan Pusat Statistik Provinsi Jawa Barat. 2017. Produksi Hortikultura Sayuran dan Buab Semusim Provinsi Jawa Barat.

Badan Pusat Statistik. 2017. Penduduk Berumur 15 Tahun Ke Atas yang Bekerja Selama Seminggu yang Lalu Menurut Lapangan Pekerjaan Utama dan Jenis Kelamin Agustus 2015.

David, Fred R. 2009. Strategic Management: Manajemen Strategi Konsep. Jakarta: Salemba Empat

Direktorat Jenderal Hortikultura Kementerian Pertanian. 2018. Laporan Kinerja 2018. Jakarta.

Prawitasari, Sri Yati. 2010. Analisis SWOT Sebagai Dasar Perumusan Strategi Pemasaran Berdaya Saing (Studi pada Dealer Honda Tunggul Sakti di Semarang). Skripsi. Fakultas Ekonomi. Universitas Diponegoro: Semarang.

Rangkuti, Freddy. 2014. Analisis SWOT: Teknik Membedah Kasus Bisnis. Jakarta: PT. Gramedia Pustaka Utama.

Riduwan. 2010. Skala Pengukuran VariabelVariabel Penelitian. Bandung: Alfabeta

Sugiyono. 2011. Statistika Untuk Penelitian. Bandung: Alfabeta.

$\begin{array}{lccr}\text { RUMUSAN } & \text { STRATEGI } & \text { BISNIS SUB } \\ \text { TERMINAL } & \text { AGRIBISNIS } & \text { CIGOMBONG } \\ \text { KECAMATAN } & \text { PACET } & \text { KABUPATEN } \\ \text { CIANJUR } & & \end{array}$

